\title{
Peripheral plasma prolactin concentrations during oestrous cycles in different types of primitive gilt
}

\author{
Joanna Gromadzka-Ostrowska, A. Madej* and B. Barcikowski†
}

Physiological Laboratory, Warsaw Zoological Garden, 03-461 Warsaw, Ratuszowa 1/3, and $\dagger$ Institute of Animal Physiology and Nutrition, Polish Academy of Sciences, 05-110 Jablonna near Warsaw, Poland

\begin{abstract}
Summary. Plasma prolactin concentrations were determined by radioimmunoassay during oestrous cycles and around the time of oestrus in different types of primitive gilts: Vietnamese, Zlotnicka and wild-boar $\times$ domestic pig hybrids. The animals were bled without stress from an indwelling arterial catheter. The following results were obtained: (1) in all gilts the main prolactin peak was observed at Day 15 or 16 of the oestrous cycle; (2) Vietnamese and hybrid gilts showed a second smaller prolactin surge after (Day 2) or before (Day 17) oestrus; (3) base levels of prolactin during the oestrous cycle were $14.8 \pm 0.93 \mathrm{ng} / \mathrm{ml}$ (Vietnamese gilts), $13.2 \pm 1.05 \mathrm{ng} / \mathrm{ml}$ (Zlotnicka gilts) and $15 \cdot 6 \pm 2 \cdot 01 \mathrm{ng} / \mathrm{ml}$ (hybrid gilts). The 15-16-day prolactin peaks reached maximum values of $36 \cdot 4,43.4$ and $56.5 \mathrm{ng} / \mathrm{ml}$ respectively.
\end{abstract}

\section{Introduction}

Changes in prolactin concentrations in the peripheral blood during different stages of the reproductive cycle and their role in the regulating mechanism of the oestrous cycle have been studied in sheep and cattle (Davis, Reichert \& Niswender, 1971; Cumming, Brown, Goding, Bryant \& Greenwood, 1972; Kann \& Denamur, 1974; Karg \& Schams, 1974; Walton, McNeilly, McNeilly \& Cunningham, 1977). However, the physiological role of prolactin in the regulation of the oestrous cycle of the sows is unknown. Day, Anderson, Hazel \& Melampy, (1959) first reported that prolactin in pigs increased before oestrus and Denamur \& Mauleon (1963) considered that prolactin was not luteotrophic in pigs. Some recent studies have suggested that prolactin in pigs is luteolytic rather than luteotrophic (Brinkley, Wilfinger \& Young, 1973; Threlfall, Dale \& Martin, 1974; van Landeghem \& van de Wiel, 1977; Dusza \& Krzymowska, 1979).

As demonstrated by Gromadzka-Ostrowska (1980), primitive pigs have very regular oestrous cycles and the hormonal events during the cycles are more regular than in other pig breeds. It was therefore considered possible that primitive pigs could be used to investigate the role of prolactin in the regulation of the oestrous cycle.

\section{Materials and Methods}

Three types of primitive pigs were used: primitive Asiatic domestic pigs, i.e. Vietnamese (Sus scrofa vittatus), primitive European domestic pigs, i.e. Zlotnicka (Sus scrofa domestica) and first

\footnotetext{
* Present address: Department of Clinical Chemistry, Faculty of Veterinary Medicine, Swedish University of Agricultural Sciences, S-750 07 Uppsala, Sweden. 
generation of wild boar $\times$ domestic pig hybrids (Sus scrofa ferrus $\times$ Sus scrofa domestica). Adult females, 14-19 months old, were used: 4 Vietnamese pigs, 3 Zlotnicka pigs and 2 hybrids.

Vietnamese pigs are native to south-east Asia and descended from the wild Asiatic hog (Sus vittatus). They have a fat body with very short legs and a smooth hide, dark grey in colour. The head is strikingly massive and large in proportion to the pig's size. The face is extremely short, the muzzle is very broad and blunt, and the erect ears are small. Zlotnicka pigs are native to Poland, descended from the wild European boar (Sus scrofa ferrus). They have a spotty coat, a cream-coloured hide with black patches variously distributed over the body. The body is long, the head is small with a narrow muzzle and large flapping ears. On the back and neck single cream-coloured bristles may be present. Both types of pig have a cycle about 20 days in length which recurs all the year round as in the other domestic pigs. The hybrid pigs appeared similar to European wild boar (Sus scrofa ferrus) with its strong short body, dense dark brown and black bristles with longer bristles along the midline of the back and neck, long legs and straight tail. The head is large with big erect ears and a narrow muzzle. These hybrids had an oestrous cycle of about 18 days in length which recurs all the year round as in domestic pigs.

The animals were housed individually under natural light conditions. The gilts were examined daily and symptoms of oestrus (the standing response amongst other signs) were used to confirm onset of heat. Two oestrous cycles were recorded before starting collections of blood samples.

All animals were surgically fitted with a catheter into a femoral artery by the technique of Weirich, Will \& Crumpton (1970). The pigs, weighing 80-100 kg, were tranquillized with azaperone and metomidate (Stresnil and Hypnodil: Janssen Pharmaceutical, Belgium.) The catheter, $1 \mathrm{~m}$ long and $2.3 \mathrm{~mm}$ o.d., was filled with heparin $(500 \mathrm{i} . \mathrm{u} . / \mathrm{ml})$ after withdrawing the blood samples and was corked with a Teflon stopper.

Blood samples were collected daily between $08: 00$ and $09: 00 \mathrm{~h}$ during 2-3 oestrous cycles into a tube containing heparin. During the oestrous period $(60-70 \mathrm{~h})$ blood samples were taken more frequently at 3 -h intervals. Plasma samples were stored at $-20^{\circ} \mathrm{C}$ until assayed.

Plasma prolactin concentrations were determined by a highly specific double-antibody radioimmunoassay technique using a purified porcine prolactin (KK-2 purified by $\mathrm{K}$. Kochman) as antigen (see Kochman \& Kochman, 1977). The antibody showed no cross-reaction with purified porcine GH, LH and ACTH. Porcine prolactin was iodinated by a modification of the method of Bryant \& Greenwood (1968) using $1.2 \mathrm{mCi}^{125}$ I (Institute of Nuclear Research, Swierk, Poland) and $17 \mu \mathrm{g}$ chloramine $\mathrm{T}$. The labelled porcine prolactin was purified on a Sephadex G-75 column equilibrated with $0.07 \mathrm{M}$-veronal buffer, $\mathrm{pH} 8 \cdot 6$. The sensitivity of the assay was $0 \cdot 20 \mathrm{ng} / \mathrm{ml}$ plasma. The intra- and inter-assay coefficients of variation were $3 \%$ and $10 \%$ respectively.

Phases of the oestrous cycle were determined according to the plasma concentrations of LH and progesterone, which were measured by radioimmunoassays. These data have been described previously (Gromadzka-Ostrowska \& Barcikowski, 1983). The day of oestrus was considered as Day 0 of the cycle.

Mean group values and their standard errors were calculated for each day of the oestrous cycle. After preliminary inspection of individual and group results, statistically significant differences between prolactin concentration at Days 1,2,10,12,15, 16, 17 and cycle basal prolactin levels were determined by Student's $t$ test.

\section{Results}

Inspection of the results revealed that the pattern of changes in prolactin concentrations throughout the oestrous cycle were similar in the Vietnamese and hybrid gilts and a little different in the Zlotnicka gilts. 
Oestrous cycle

Vietnamese gilts. The oestrous cycle was 19-20 days in length. Typical oestrous symptoms were observed in all 4 animals ( 8 cycles). As shown in Text-fig. 1, basal prolactin concentration was $14 \cdot 8$ $\pm 0.93 \mathrm{ng} / \mathrm{ml}$ and averaged from $7 \cdot 1$ to $15.0 \mathrm{ng} / \mathrm{ml}$ plasma between Days 3 and 15 , then increased significantly to a maximum value of $36.4 \mathrm{ng} / \mathrm{ml}$ at Day 16 and declined to $13.5 \mathrm{ng} / \mathrm{ml}$ at Day 18 . At Day 2 a small rise $(P<0.05)$ in plasma prolactin concentration $(19.5 \mathrm{ng} / \mathrm{ml})$ was observed.

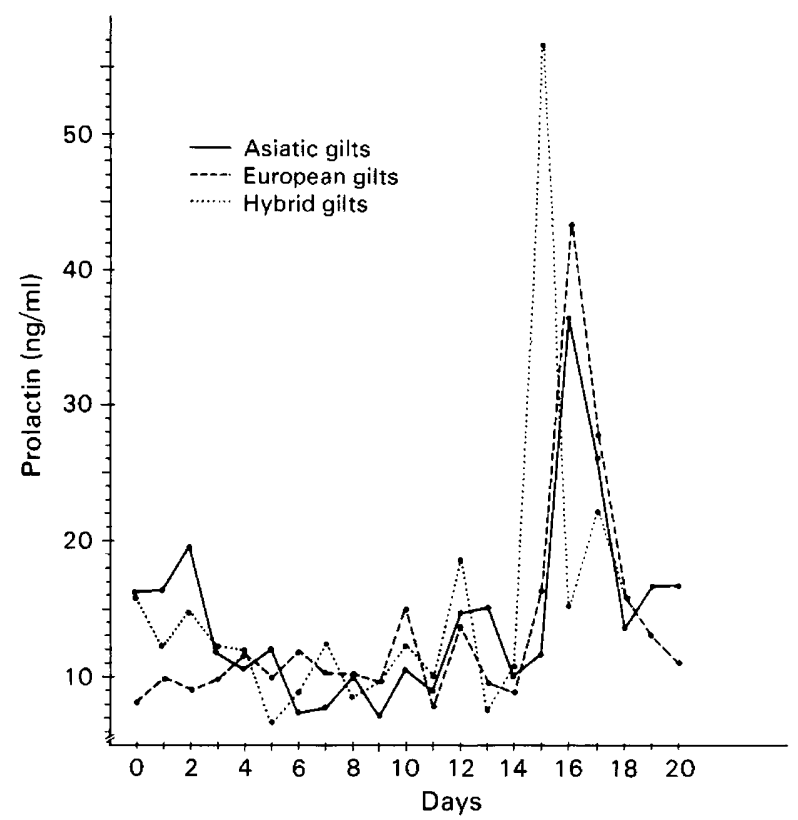

Text-fig. 1. Plasma prolactin concentrations in primitive Asiatic (Vietnamese), primitive European (Zlotnicka) and hybrid gilts during the oestrous cycle. Day $0=$ first day of oestrus.

Zlotnicka gilts. Oestrous cycles averaged 19-20 days and clear oestrous symptoms were observed in all 3 animals ( 4 cycles). Basal values of prolactin (Text-fig. 1) were $13.2 \pm 1.05 \mathrm{ng} / \mathrm{ml}$ plasma and oscillated from 7.7 to $14.9 \mathrm{ng} / \mathrm{ml}$ between Day 0 and Day 14 . Only one low rise occurred at Day 10 $(P<0.05)$. On Day 15 prolactin concentration increased significantly $(P<0.001)$ and reached maximal value of $43.4 \mathrm{ng} / \mathrm{ml}$ at Day 16 . Values then declined and remained basal until the end of the cycle. No rise in prolactin concentration was observed at oestrus.

Hybrid gilts. The length of the oestrous cycle was 18 days ( 2 gilts, 4 cycles) and clear oestrous symptoms were observed on Day 0 . The profile of the prolactin concentration (Text-fig. 1) was in general similar to those of the Vietnamese and Zlotnicka gilts.

During most of the oestrous cycle (Days 0 to 14) plasma prolactin concentration was basal (15.6 $\pm 2.01 \mathrm{ng} / \mathrm{ml}$ ). At Day 15 prolactin level increased significantly to $56.5 \mathrm{ng} / \mathrm{ml}$ and then decreased to $15 \cdot 1 \mathrm{ng} / \mathrm{ml}$ at Day 16. The rise on Day 17 was not significant.

\section{Time around oestrus}

Four gilts (A and B, Vietnamese; C, Zlotnicka; D, hybrid) were bled frequently at 3-h intervals from the first signs of standing heat until $60 \mathrm{~h}$. 

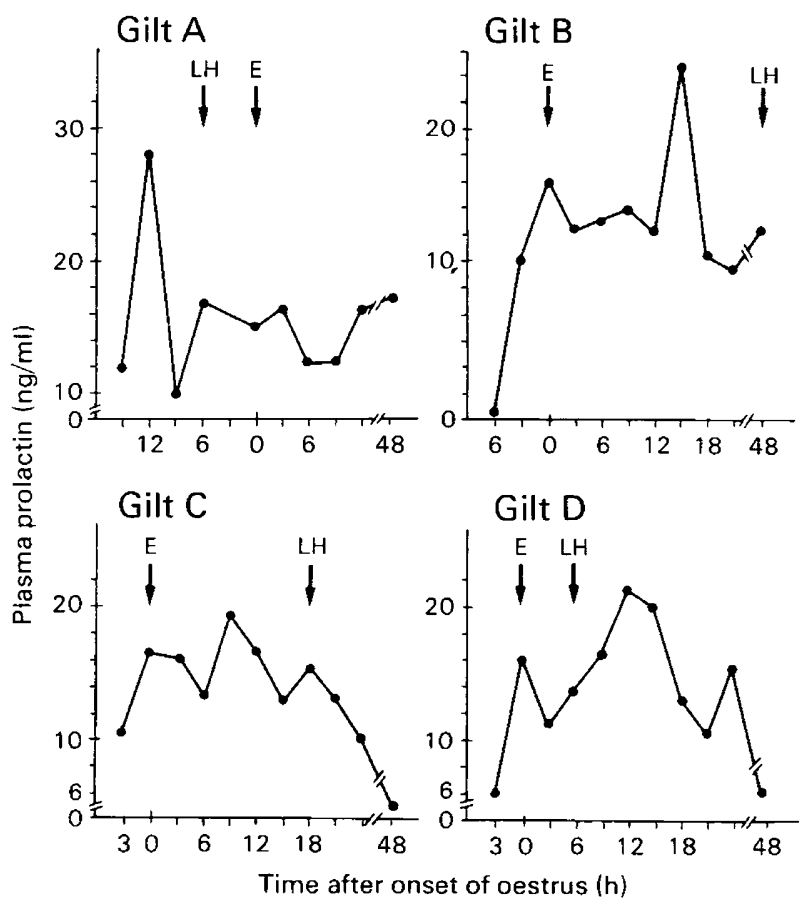

Text-fig. 2. Plasma prolactin concentrations around oestrus in primitive gilts (A, B: Vietnamese; C, Zlotnicka; D, hybrid). E, first signs of standing heat; LH, preovulatory LH peak.

In relation to the onset of standing heat and the LH peak (the LH data, measured according to Strupnicki \& Madej (1970), are from a previous report (Gromadzka-Ostrowska, 1980)), the midoestrous prolactin rise occurred respectively at 12 and $6 \mathrm{~h}$ in Gilt A, 15 and $33 \mathrm{~h}$ in Gilt B, 9 and $9 \mathrm{~h}$ in Gilt $\mathrm{C}$ and 12 and $6 \mathrm{~h}$ in Gilt $\mathrm{D}$ (Text-fig. 2).

\section{Discussion}

When collecting blood samples for prolactin determination it has been considered that stress may influence prolactin secretion (Schams, 1974; Ferland, Kledzik, Cusan \& Labrie, 1978). Also, the bleeding method was found to influence the plasma prolactin concentration (Raud, Kidley \& Odell, 1971) although prolactin concentration appear to be significantly less sensitive to handling and sampling stress in the pig than in other domestic species (Smith \& Wagner, 1980; Hoagland, Diekman \& Malven, 1981). In our experiments we tried to avoid stress as much as possible by using a long indwelling catheter. Many workers have strongly suggested the existence of circadian rhythms of prolactin level with the highest value in the early morning and the lowest between 16:00 and 22:00 h (Stupnicki, Madej \& Dobrowolski, 1974; Lamming, Moseley \& McNeilly, 1974). To minimize these diurnal hormonal fluctuations blood samples were collected in our experiments always at the same time of day.

As was described by Ravault et al. (1982) for wild boars and sows, plasma prolactin varied among season with the highest levels in July and the lowest during the winter months. The influence of light on prolactin secretion in domestic pigs is small, but plasma prolactin values of gilts tended to be higher in the summer than in the winter. In our study collections of blood samples 
from all primitive pigs were taken during the winter and spring months (February, March and April), thus eliminating seasonal differences in plasma prolactin concentration.

In all the primitive gilts investigated, basal prolactin levels during oestrous cycle ranged from 13.2 to $15.6 \mathrm{ng} / \mathrm{ml}$ plasma. These values are higher than those reported by others: $2-10 \mathrm{ng} / \mathrm{ml}$ (van Landeghem \& van de Wiel, 1977), $6 \cdot 15 \mathrm{ng} / \mathrm{ml}$ (Brinkley et al., 1973), 8.7-10.5 ng/ml (Ravault et al., 1982), 3-20 ng/ml (Dusza \& Krzymowska, 1979). Differences with respect to the absolute concentrations found in our study can probably be related to differences in hormonal status in primitive pigs rather than to the assay methodology. As described previously (GromadzkaOstrowska, 1980) primitive pigs have higher concentrations of LH, progesterone, oestrogens, androgens and cortisol, although the secretion patterns are similar to those of other pigs. Similar observations have been made by Ravault et al. (1982), confirming that in wild sows prolactin concentrations are higher than in domestic breeds.

The profiles of prolactin concentrations found during the oestrous cycle of three primitive types of pigs in the present study are in general similar to those previously described for other breeds. In all three types a main prolactin peak was at Day 15 or 16 of the cycle, as found by other workers (Day et al., 1959; Brinkley, Rayford \& Young, 1972; Brinkley et al., 1973; Threlfall et al., 1974; van Landeghem \& van de Wiel, 1977; Dusza \& Krzymowska, 1979) with domestic pigs, in which the highest prolactin concentrations were during the luteal phase between Days 17 and 19. A second smaller prolactin rise, 1-2 days before or after oestrus, was found in Vietnamese gilts. The increase in prolactin concentration at oestrus was not significant in hybrid gilts and was not found in Zlotnicka gilts.

The changes in prolactin level around oestrus were similar to those described by van Landeghem \& van de Wiel (1977) and Bevers, Willemse \& Kruip (1978) and coincided more or less with the ovulatory surge of LH. Dusza \& Krzymowska (1979) also reported that the prolactin peak occurred before the LH peak. In rats (Kwa \& Verhofstad, 1967; Wuttke, Cassel \& Meites, 1971) and sheep (Kann \& Denamur, 1974) the ovulatory surge of LH is accompanied by a prolactin release. Prolactin might therefore be involved or at least associated with alterations in the secretion and release of $\mathrm{LH}$. A possible role of prolactin in the functioning of the ovary in sows in connection with LH and progesterone was suggested by van Landeghem \& van de Wiel (1977): they considered that the surge of prolactin during oestrus may be indicative of its luteotrophic function, although the main prolactin surge coinciding with a decrease in progesterone concentration might indicate a luteolytic role. This increase in prolactin secretion during luteolysis could represent some effects of prostaglandins from the pig's uterus where their production may be promoted by oxytocin (Ellendorff et al., 1979).

Oestrogens have also been shown to increase prolactin secretion in rats (Amenomori \& Meites, 1970) and ewes (Fell, Beck, Brown, Cumming \& Goding, 1972) and it has been suggested that the pro-oestrous rise in prolactin concentration is related to the increasing levels of oestradiol during the preovulatory period (McNeilly, 1980). Dusza \& Krzymowska (1979) also suggested that during the oestrous cycle of the sow the increase in prolactin concentration was probably caused by oestrogens.

As shown in the previous study (Gromadzka-Ostrowska, 1980), oestrogens began to rise and progesterone concentrations decrease at Day 16 (Vietnamese and Zlotnicka gilts) or at Day 15 (hybrid gilts) when prolactin concentration in the same animals increased markedly. Also, an increase of prolactin concentration around oestrus seems to coincide with a rise of the oestrogen concentration rather than to increase $\mathrm{LH}$ secretion. These observations could suggest that prolactin in the pig has more of a luteolytic than a luteotrophic role.

We thank Dr K. Kochman, Institute of Animal Physiology and Nutrition, for the gift of purified porcine prolactin standard; Mrs E. Szylarska and Mrs B. Zalewska for their valuable assistance in animal care and blood sampling; and Dr J. Goslawski, Warsaw Zoological Garden, for tranquillizing the animals at the surgery. 


\section{References}

Amenomori, Y. \& Meites, J. (1970) Effect of a hypothalamic extract on serum prolactin levels during the estrus cycle and lactation. Proc. Soc. exp. Biol. Med. 134, 492-495.

Bevers, M.M., Willemse, A.H. \& Kruip, Th.A.M. (1978) Plasma prolactin levels in the sow during lactation and the post weaning period as measured by radioimmunoassay. Biol. Reprod. 19, 628-634.

Brinkley, H.J., Rayford, P.L. \& Young, E.P. (1972) Porcine prolactin radioimmunoassay. J. Anim. Sci. 35, 237, Abstr.

Brinkley, H.J., Wilfinger, W.W. \& Young, E.P. (1973) Plasma prolactin in the estrous cycle of the pig. $J$. Anim. Sci. 37, 303, Abstr. 291.

Bryant, G.D. \& Greenwood, F.C. (1968) Radioimmunoassay for ovine, caprine and bovine prolactin in plasma and tissue extracts. Biochem. J. 108, 831-840.

Cumming, I.A., Brown, J.M., Goding, J.R., Bryant, G.D. \& Greenwood, F.C. (1972) Secretion of prolactin and LH at oestrus in the ewe. J. Endocr. 54, 207-213.

Davis, S.L., Reichert, L.E. \& Niswender, G.D. (1971) Serum levels of prolactin in sheep as measured by radioimmunoassay. Biol. Reprod. 4, 145-153.

Day, B.N., Anderson, L.L., Hazel, L.N. \& Melampy, R.M. (1959) Gonadotrophic and lactogenic hormone potencies of gilt pituitaries during the estrous cycle and pregnancy. J. Anim. Sci. 18, 675-681.

Denamur, R. \& Mauléon, P. (1964) Controle endocrinien de la persistance du Corps Jaune chez les Ovins. $C$. $r$. hebd. Séanc. Acad. Sci., Paris-D 257, 527-533.

Dusza, L. \& Krzymowska, H. (1979) Plasma prolactin concentration during the oestrous cycle of sows. $J$. Reprod. Fert. 57, 511-514.

Ellendorf, F., Forsling, M., Parvizi, N., Williams, H., Taverne, M. \& Smidt, D. (1979) Plasma oxytocin and vasopressin concentrations in response to prostaglandin injection into the pig. J. Reprod. Fert. 56, 573-577.

Fell, L.R., Beck, C., Brown, J.M., Cumming, J.A. \& Goding, J.R. (1972) Radioimmunoassay for ovine prolactin. The secretion of prolactin as affected by milking, oestradiol administration and onset of parturition. J. Reprod. Fert. 28, 133-134.

Ferland, L., Kledzik, G.S., Cusan, L. \& Labrie, F. (1978) Evidence for a role of endorphins in stress and suckling-induced prolactin release in the rat. Molec. cell. Endocr. 12, 267-272.

Gromadzka-Ostrowska, J. (1980) Hormonal secretion patterns during oestrous cycle of different types of primitive pigs. Ph.D. thesis, Warsaw University. (In Polish.]

Gromadzka-Ostrowska, J. \& Barcikowski, B. (1983) LH and progesterone concentrations in peripheral plasma during the oestrous cycle of the primitive pigs. Zesz. probl. Postep. Nauk roln. 261, 62-64.

Hoagland, T.A., Diekman, M.A. \& Malven, P.V. (1981) Failure of stress and supplemental lighting to effect release of prolactin in swine. J. Anim. Sci. 53, 467472.
Kann, G. \& Denamur, R. (1974) Possible role of prolactin during the oestrous cycle and gestation in the ewe. $J$. Reprod. Fert. 39, 473-483.

Karg, H. \& Schams, D. (1974) Prolactin release in cattle. J. Reprod. Fert. 39, 463-472.

Kochman, K. \& Kochman, K. (1977) Purification of ovine and bovine prolactins on DEAE-cellulose chromatography and preparative polyacrylamide gel electrophoresis. Bull. Acad. pol. Sci. Cl.II. Sér. Sci. 25, 6770.

Kwa, H.G. \& Verhofstad, F. (1967) Prolactin levels in the plasma of female rats. J. Endocr. 39, 455-456.

Lamming, G.E., Moseley, S.R. \& McNeilly, J.R. (1974) Prolactin release in the sheep. J. Reprod. Fert. 40, 151-168.

McNeilly, A.S. (1980) Prolactin and the control of gonadotrophin secretion in the female. J. Reprod. Fert. 68, 537-549.

Raud, H.R., Kidley, C.A. \& Odell, W.D. (1971) The effect of stress upon the determination of serum prolactin by radioimmunoassay. Proc. Soc. exp. Biol. Med. 136, 689-693.

Ravault, J.P., Martinat-Botte, F., Mauget, R., Martinat, N., Locatelli, A. \& Bariteau, F. (1982) Influence of the duration of daylight on prolactin secretion in the pig: hourly rhythm in ovariectomized females, monthly variation in domestic (male and female) and wild strains during the year. Biol. Reprod. 27, 1084-1089.

Schams, D. (1974) Untersuchungen uber Prolactin beim Rind. Verlag Parey, Hamburg.

Smith, B.B. \& Wagner, W.C. (1980) Influence of stress on circulating prolactin concentrations in the postpartum sow. J. Anim. Sci. 51, Suppl. 1, 330, Abstr.

Stupnicki, R. \& Madej, A. (1970) Radioimmunoassay of LH in blood plasma of farm animals. Endokrynologie 68, 6-13.

Stupnicki, R., Madej, A. \& Dobrowolski, W. (1974) Circadian rhythm of plasma prolactin levels in cows. Gen. comp. Endocr. 22, 383.

Threlfall, W.R., Dale, H.E. \& Martin, C.E. (1974) Porcine blood and hypophyseal prolactin values. Am. J. vet. Res. 35, 1491-1493.

van Landeghem, A.H.J. \& van de Wiel, D.F.M. (1977) Plasma prolactin levels in gilts during the oestrous cycle and at hourly intervals around the time of oestrus. Acta endocr., Copenh., Suppl. 212, 143, Abstr.

Walton, J.S., McNeilly, J.R., McNeilly, A.S. \& Cunningham, F.C. (1977) Changes in the concentrations of $\mathrm{FSH}, \mathrm{LH}$, prolactin and progesterone in the plasma of ewes during the transition of anoestrous to breeding activity. J. Endocr. 75, 127-136.

Weirich, W.E., Will, J.A. \& Crumpton, C.W. (1970) A technique for placing chronic indwelling catheters in swine. J. appl. Physiol. 28, 117-119.

Wuttke, W., Cassel, E. \& Meites, J. (1971) Effects of ergocornine on serum prolactin and LH and on hypothalamic content of PIF and LRF. Endocrinology 88, 737-741. 